\title{
Secularism - An Impractical Idea
}

Govinda K. Shah

\begin{abstract}
The article explores the various meanings and concepts of secularism presented by famous ideologues and sociologists of their time. Two contrary concepts of the secularism - one that defines secularism as denial of existence of religions or supernatural forces and another that defines secularism as concept of peaceful co-existence and mutual harmony has been discussed here. The difference of application of secularism on the individual human being and a state is also explained here. The article concludes that no state of human being can remain isolated or indifferent from the influence of religion even if they want. None of the concepts of secularism apply in real life performances; neither on individual nor state.
\end{abstract}

Keywords: Secularism, Religion, Christianity, Church, State, Communist, Atheist, Humanity

\section{Introduction}

Defining secularism is a very complex task. Secularism is not simply a concept, as understood widely, where the government of nations and their entities keep religion separate from state affairs. Secularism is something much more complex than this widely advertised definition. Does secularism mean elimination of religion? Is it merely a 
separation of state and religion? Could a human being really be secular completely denying the existence of god? Even if one denies the existence of religion, could he/she live a life completely detaching himself/herself forms the judgments, which is shaped by religion? Numerous questions can be raised when it comes to define secularism.

Defining the word - secularism has become a complex task because on the one hand, secularism has been emerging as an idea of denial of religion while on the other hand, secularism has been also emerging as an idea of tolerance and mutual coexistence among the various religions of the world. The first idea tries to completely eliminate the existence of god. This idea tends to develop the concept of secularism in the way where there is no place for any supernatural power at all while the second idea does not reject the idea that there is the existence of gods in this world. Hence, this idea attempts to explain the secularism in the way, which beliefs in creating a state of peaceful and mutual co-existence between the followers of the different religions within a single society. These two ideas are opposite of each other, but both ideas are being practiced in current scenario simultaneously in the globe. This very fact makes the task of defining secularism a complex one and challenging for thinkers/scholars. The latter part of this article attempts to explain the various concepts of secularism and present a clear picture on it.

\section{Overview}

Professor of National University of Singapore TEN CHIN LIEW defines secularism with two different views, which are 
conflicting with one another. The first view is of the 'perspectival secularism' and the second is of the 'state secularism'. Heng \& Ten (2010) describe perspectival secularism as it is an alternative to the religious perspective in that it finds no place for the God. In contrary, scholars like Liew defines state secularism as an idea, which does not seek the elimination of religion; rather it confines the scope and application of the application.

Perspectival secularism is indeed hostile to religion and is an alternative to religious perspectives in that it finds no place for the God of traditional religions or the afterlife. The secular perspective regards itself as superior to all religious outlooks, which will eventually disappear. But state secularism is a different view that defines the proper functions and limits of the state. It does not seek to eliminate religion, but to confine its scope and application in various ways and for various reasons (Heng \& Ten, 2010).

French Philosopher August Comte in his doctrine of Religion of Humanity passes a similar idea with 'Perspectival secularism'. He stressed on building a kind of the society where there is no place for god and supernatural power. "While the different forms of deism preserve the idea of God and dissolve religion into a vague religiosity. Comte proposes exactly the contrary: a religion with neither God nor the supernatural" (Bourdeau, 2008). Explaining further the doctrine of Religion of Humanity, an influential British Philosopher John Stuart Mill further said that there is no need of supernatural belief. The main thing is in the development of humanity and, serving and worshiping humanity is the religion of humanity. Moreover, he accuses that the 
unfortunate tendency in supernatural religion hinders the development not only of our intellectual, but also of our moral nature. Mill argues that much of the apparent social utility of religion derives not from its dogma and theology, but to its inculcation of a widely accepted moral code, and to the force of public opinion guided by that code. The belief in a supernatural power may have had some utility in maintaining that code, but is no longer needed and may indeed be detrimental (Wilson, 2002).

A prominent English philosopher of seventeenth century, John Locke in one of his popular write-up, 'A Letter concerning Toleration' also gives an idea of secularism but contrary to the former ideas. He believes in the existence of gods or supernatural power and so advocates for respecting the different opinion on religion. "Tolerating those who differ from us in matters of religion is so fitting to the Gospel and to reason that it seems monstrous for men to fail to see this clearly" (Locke, 1689). He wrote the said letter during that period when all over in Europe, the rulers were forcing all their citizens to adopt Christianity. The rulers also had been even using the coercive methods to force people pray to Jesus and perform the Church rituals. During that critical period, Locke raised his voice against ruler in order to aware them to not impose a specific religion to every citizen of their governing territory because if the rulers do that, it is very much possible that they may impose a wrong religion. Until there are no other different opinion makers existing in society, the invention of better ideas is impossible. His idea of respecting different religious groups is similar to the idea of secularism termed as 'state secularism' by Liew, which 
accepts the existence of god but advocate for mutual coexistence of different religion.

However, there are numbers of other prominent philosophers and sociologists who, unlike the idea of Locke, out rightly reject the existence of God or any kind of supernatural power. Most revered thinkers like Comte, Durkheim, Freud, Marx, and Weber all have a common thought on religion. All of them reject of the idea of the existence of religion in the wake of their own analytical grounds.

During the age of the industrial revolution in the 18th Century in England, the society was changing rapidly towards modernization, capitalization and urbanization. Mode of production, which has changed due to technological advancement, has also changed the perspective of human towards religion. The growing dependency and belief in science, a new system of financial management led Durkheim to forecast the inevitable disbelief on supernatural religion in future. "Durkheim described it as an age in which the influence of the old gods of traditional religion was being replaced by new, more scientific ways of understanding the world" (Lynch, 2012).

It must also be mentioned here that the complexity of secularism also dragged the revolutionary philosopher Sigmund Freud, who is famous for eroticism, to have a say on it. Freud has also strongly opposed the existence of religion. Until his lifetime, he lived being an atheist. He never believed in any kind of religion or faith system. He has mentioned his strong objection to a religious belief system in many of his works. One of his highly popular works 'In the Future of an 
Illusion', he described belief in God as a collective neurosis: he called it 'longing for a father' (Edmundson, 2007).

Karl Marx, who is considered the father of communism is also famously known strong opponent of religious system. He explained religion as a tool of oppression in the capitalist system of production. According to Marx, religion is something created by the bourgeois to exploit the proletariat. Religion is one the superstructure resulted due to the capitalist mode of production. He suggests that the abolition of religion is necessary to end the domination. He even pronounced religion as opium.

Religious suffering is, at one and the same time, the expression of real suffering and a protest against real suffering. Religion is the sigh of the oppressed creature, the heart of a heartless world, and the soul of soulless conditions. It is the opium of the people. The abolition of religion as the illusory happiness of the people is the demand for their real happiness. To call on them to give up their illusions about their condition is to call on them to give up a condition that requires illusions. The criticism of religion is, therefore, in embryo, the criticism of that vale of tears of which religion is the halo (Marx, 1844).

Poet and philosopher Friedrich Wilhelm Nietzsche's insight towards religion is that "without blood, torture and sacrifice, including 'disgusting mutilations', what we know as 'modern psychology' would never have arisen. All religions are at bottom systems of cruelty" (Nietzsche, Ansell-Pearson \& Diethe, 2006). He opines that every man should be kept sovereign. No religion should direct a man how to live. There are no rules for human, no absolute norms and no certainty 
upon which human should rely. People would be more moral, more honest and more disciplined in the world without religion as all religions are at bottom systems of cruelty.

French writer Voltaire has made a straightforward statement in support of religious tolerance in his letter on England. If one religion only were allowed in England, the Government would very possibly become arbitrary; if there were but two, the people would cut one another's throats; but as there is such a multitude, they all live happy and in peace (Voltaire, 1778).

This response of Voltaire was against the Kingdom of England, who was trying hard to establish a single religion as the religion of its entire citizen. His statement not only criticizes loudly the attempt of making a state of a single religion but also justifies the necessity of multi-religion in order to maintain peace in society.

Max Weber in his work 'the sociology of religion describes, "Secular philosophy was a very important component of religious development. Hence, we must now examine more closely the mutual relationships of priests, prophets, and nonpriests" (Weber, Roth \& Wittich, 2013)

Wrapping up the famous ideas presented by the abovementioned ideologue and philosophers, secularism could be defined in two ways. The first way is denial of god and second way is not denying the existence of the god or any kind of similar divine entity, rather to accept and respect all other ideologies on god. The concept of secularism should be distinguished as 'secular human' and 'secular state'. Being secular human and being secular state are two different things. Individuals and states must be considered separately while 
defining secularism. To be a secular human being, s/he must deny the existence of God completely. To be a secular state, she can adopt two ways. Either she can completely deny existence of god and dissociated herself with religion or she can accept the existence of god and adopt the secularism as a way of peaceful co-existence and mutual harmony. In conclusion, there are two different essences of secularism. First essence is to completely eliminate the god and supernatural factors. There should not be any position for supernatural religion in the world. An individual secular human being mainly follows this essence while the second essence of secularism accepts the presence of religion; but not only one religion. It stresses on mutual co-existence of different religions in world. A secular state follows this essence.

But, in my personal opinion, secularism is mere an ideology, it is not pragmatically possible. Neither a human being, nor a state could actually be secular. An individual or a state may claim itself secular, but it's not possible to be secular to the extent defined by above philosopher. Let think of a human being who claim him/herself secular. S/he may deny the existence of god. S/he may not believe on any supernatural power. S/he may also not follow the religious ritual. S/he may not visit any temple, mosque, church or any center of devolution. But s/he could not deny the way of living in which his/her society is living. Human lives in a family. Families live under a social structure. Every family and every society have certain rules under which they survive. The rules dictate the different roles and duties of family members. From birth to death, an individual should perform his/her duties according to a set rule created by society. One should marry, 
give birth to s child, grow up the child, look after the old parent and this cycle is performed by every generation. And an individual cannot perform this all duties in the absence of a faith, which basically has been inculcated by religion in the society. Even one wants, it's not possible because the source of the rules comes from religion.

A society creates rules and duties for an individual on the basis of religious faith. It doesn't matter how much secular one is, no one could isolate religion from the society. Society always defines the way of living life, making religion the base. Thus, all individuals who live under a society cannot isolate $\mathrm{him} / \mathrm{her}$ from the influence of religion. S/he may claim him/herself secular, but could not be secular in real life performance.

Similarly, talking about a secular state, it is also not practically possible. First of all, we must look into the fact that there are many states in this world those have an official religion. According to Pew Research Centre, there are at least 30 countries in this world those should have a head of state from a particular religion (Theodorou, 2014). These are the states, which have declared a particular religion as her official religion. But, let us look at the differences in theory and practices of the countries which constitution says them secular state.

There are many countries representing from Europe, East Asia and South-East Asia, Middle East and Africa including America whose constitution says that their state will not discriminate her citizen on the basis of religion, all the religion will be treated equally. But, it is not true in practice. Every state having official secular constitution also follows a 
particular religion. Secular states must have to follow the religion of the majority of her citizens. After all, the majority always decides the state affairs. Taking about the oldest and most powerful democracy United States, The President always should use the Bible in oath taking ceremony. Constitutionally, it is not necessary to take oath on the Bible, but every president did the same. President Thore Rosevelt was only exception, who did not take oath on Bible in 1901. Similarly, also in the world's one of oldest democracy; the Great Britain, there is still a role of the Church of England. "The Church of England also has a law-making role in Britain. Twenty-six bishops (including the two Archbishops) sit in the House of Lords and are known as the Lords Spiritual. They are thought to bring a religious ethos to the secular process of law" ("BBC - Religions - Christianity: Church of England", 2011). Let us analyze the Article 53 of the Polish Constitution, it says that freedom of conscience and religion shall be ensured to everyone. Furthermore, in the same article, it is mentioned, "the religion of a church or other legally recognized religious organization may be taught in schools, but other peoples' freedom of religion and conscience shall not be infringed thereby" ("The Constitution of the Republic of Poland", 1997). We must notice that it gives special focus on religion of the church. Also, Polish Government provides public holiday during whole Christmas, but not in Jews or another minorities' festival. Most of the other European Nations do the same. Why? The simple reason is that Christianity in Europe is a religion of the majority.

Similar things happen in Nepal. Nepal has been a recently declared as the secular country. Despite its declaration, the president of Nepal participates in all the festival of Hindus as 
it practiced earlier in non-secular situation. In some festival, Presidents' participation is mandatory. One may ask about People's Republic of China, which prohibits religion by the constitution. But, is it possible to eradicate the thoughts of Tao or Confucius, which is still in inherent in the life of Chinese people? No, it is not possible to simply eliminate the faith of a society. Thus, I would say that like a human being, a state being secular is also not possible.

\section{Conclusion}

Any of a human being can claim him/her a secular human being. Any of a state claims herself a separate. However, none of any states of human beings can actually remain secular in real life world.

Still it does not mean that all the explanations made on secularism by afore-mentioned great ideologue and philosophers should be avoided out rightly. Though, their conclusion of complete denial of god and keeping faith on many religions is less effective; the context and the analytical framework, based on which the philosophers have floated their ideas, must be considered positively. Locke and Voltaire's argument for respecting all other religion and multitude comes on the forth ground where the states were aggressively spreading Christianity, enforcing her citizens to believe in one god and adopt a certain way of praying or faith keeping. In this context, the argument made by them was a very much necessary argument of the time. Similarly, Marx's interpretation of religion as tool of suppression, Durkheim forecast of the end of religion because of development of 
science and Freud explanation of religion as something like longing for father have strong analytical framework. The basis of their conclusion is not wrong. But, real life world does not seem to follow the way defined or forecasted by any of these philosophers. Even in the height of the scientific era, human beings as well as states like to be associated with religions.

However, the above ideas of secularism have a great contribution in changing the political system in many countries across the world including Nepal. Raising the awareness of people led people to revolt against the states, which tried to enforce religion on the state affairs. During the medieval period, goals of states and goal of Churches used to be the same. States and the Churches had been closely tiedup. The decision of state affairs was used to be made according to direction from churches. Gradually, people started to revolt against the Church, which gave the birth of the new idea of separation of state and Church.

\section{References}

BBC - Religions - Christianity: Church of England. (2011).

Retrieved from

http://www.bbc.co.uk/religion/religions/christianity/cofe/c ofe_1.shtml

Bourdeau, M. (2008). Auguste Comte (Stanford Encyclopedia of Philosophy). Retrieved from http://plato.stanford.edu/entries/comte/\#RelHum

Edmundson, M. (2007). Relgion and Faith - Sigmund Freud Atheism. Retrieved from 
http://www.nytimes.com/2007/09/09/magazine/09wwlnlede-t.html?pagewanted $=$ all\&_r $=0$

Heng, M., \& Ten, C. (2010). State and secularism (p. 7).

[Hackensack] New Jersey: World Scientific.

Locke, J. (1689). A Letter Concerning Toleration [Ebook].

Retrieved from

https://socialsciences.mcmaster.ca/econ/ugcm/3113/locke/t oleration.pdf

Lynch, G. (2012). Emile Durkheim: religion - the very idea, part 2: new forms of the sacred | Gordon Lynch. Retrieved from

http://www.theguardian.com/commentisfree/2012/dec/17/ emile-durkheim-religion-sacred

Marx, K. (1844). Marx, A Contribution to the Critique of Hegel's Philosophy of Right 1844. Retrieved from http://www.marxists.org/archive/marx/works/1843/critiqu e-hpr/intro.htm\#05

Nietzsche, F., Ansell-Pearson, K., \& Diethe, C. (2006). On the genealogy of morality. Cambridge: Cambridge University Press.

Penn State WebAccess Secure Login:. (1733). Retrieved from http://www2.hn.psu.edu/faculty/jmanis/voltaire/letters-onengland.pdf

The Constitution of the Republic of Poland. (1997). Retrieved from

http://www.sejm.gov.pl/prawo/konst/angielski/kon1.htm

Theodorou, A. (2014). In 30 countries, heads of state must belong to a certain religion. Retrieved from

http://www.pewresearch.org/fact-tank/2014/07/22/in-30countries-heads-of-state-must-belong-to-a-certainreligion/ 
Voltaire. (1778). Letters on England By Voltaire, Free PDF, ebook | Global Grey. Retrieved from https://www.globalgreyebooks.com/letters-on-englandebook/

Weber, M., Roth, G., \& Wittich, C. (2013). Economy and society (p. 455). Berkeley: University of California Press.

Wilson, F. (2002). John Stuart Mill (Stanford Encyclopedia of Philosophy). Retrieved from http://plato.stanford.edu/entries/mill/\#VieRel

Author's email: doc.govinda@gmail.com 